\title{
Pengaruh Likuiditas, Leverage, dan Profitabilitas Terhadap Nilai Perusahaan Pada Perusahaan Farmasi
}

\section{Ni Komang Yulan Surmadewi ${ }^{1}$ I Dewa Gede Dharma Saputra ${ }^{2}$}

\author{
${ }^{1}$ Fakultas Ekonomi dan Bisnis Universitas Udayana (Unud), Bali, Indonesia \\ E-mail: ysurmadewi@gmail.com \\ ${ }^{2}$ Fakultas Ekonomi dan Bisnis Universitas Udayana (Unud), Bali, Indonesia
}

\begin{abstract}
ABSTRAK
Tujuan penelitian ini adalah untuk menganalisis pengaruh likuiditas, leverage, dan profitabilitas terhadap nilai perusahaan pada perusahaan farmasi yang terdaftar di Bursa Efek Indonesia (BEI) periode 2014-2017. Populasi penelitian ini adalah perusahaan farmasi yang terdaftar di Bursa Efek Indonesia selama periode 2014-2017. Data yang dikumpulkan dengan metode purposive sampling, diperoleh sebanyak 9 perusahaan yang menjadi sampel penelitian dengan periode waktu empat tahun sehingga didapat 36 sampel penelitian. Teknik analisis data menggunakan analisis regresi linear berganda. Berdasarkan hasil analisis ditemukan bahwa variabel likuiditas tidak berpengaruh terhadap nilai perusahaan. Sedangkan variabel leverage dan profitabilitas berpengaruh secara signifikan terhadap nilai perusahaan. Hal ini menunjukkan semakin tinggi leverage dan semakin tinggi profitabilitasnya maka semakin tinggi nilai perusahaan yang diperoleh.
\end{abstract}

Kata kunci : likuiditas, leverage, profitabilitas, nilai perusahaan

\begin{abstract}
The purpose of this study is to analyze the effect of liquidity, leverage, and profitability on the value of the company on pharmaceutical companies listed on the Indonesia Stock Exchange (IDX) for the period 2014-2017. The population of this research is pharmaceutical companies listed on the Indonesia Stock Exchange during the 2014-2017 period. Data collected by purposive sampling method, obtained as many as 9 companies that became research samples with a period offour years to obtain 36 research samples. The data analysis technique uses multiple linear regression analysis. Based on the results of the analysis it was found that the variable liquidity did not affect the value of the company. While the leverage and profitability variables significantly influence the value of the company. This shows the higher leverage and the higher the profitability, the higher the value of the company obtained.
\end{abstract}

Keywords: liquidity, leverage, profitability, firm value 
Ni Komang Yulan Surmadewi dan I Dewa Gede Dharma Saputra Pengaruh Likuiditas, Leverage,...

\section{PENDAHULUAN}

Persaingan dunia usaha dalam perekonomian pasar bebas sekarang ini semakin ketat. Hal ini disebabkan semakin banyaknya perusahaan yang berdiri dan berkembang sesuai dengan bertambahnya jumlah unit usaha ataupun meningkatnya kegiatan ekonomi yang ditandai dengan meningkatnya kebutuhan pasar. Di Indonesia terdapat pasar modal yang bernama Bursa Efek Indonesia (BEI) atau Indonesian Stock Exchange (IDX). Bursa Efek Indonesia memiliki peranan penting dalam perekonomian negara, karena dapat memberikan sarana bagi masyarakat umum untuk berinvestasi dan sebagai sarana untuk mencari tambahan modal bagi perusahaan go public.

Setiap perusahaan yang telah go public tentunya menginginkan harga saham yang dijual memiliki potensi harga yang tinggi sehingga menarik minat investor untuk menginvestasikan dananya pada perusahaan tersebut. Semakin tinggi harga saham maka dapat mencerminkan semakin tinggi pula nilai perusahaan tersebut. Perkembangan bursa efek dapat dilihat dengan semakin banyaknya anggota bursa juga dapat dilihat dari perubahan harga harga saham yang diperdagangkan. Perubahan harga saham dapat memberi petunjuk tentang kegairahan dan kelesuan aktivitas pasar modal serta pemodal dalam melakukan transaksi jual beli saham.

Pada umumnya kinerja sebuah perusahaan akan berpengaruh pada harga saham perusahaan tersebut. Semakin baik kinerja suatu perusahaan maka semakin tinggi laba usaha yang akan diperoleh dan pemegang saham turut menikmati keuntungan dari penghasilan perusahaan, sehingga banyak investor yang ingin memiliki saham perusahaan tersebut dan harga saham akan naik. 
Salah satu sektor yang terdaftar di Bursa Efek Indonesia adalah subsektor farmasi. Subsektor farmasi memiliki peran dalam reformasi dibidang kesehatan. Dalam permasalahan kesehatan yang terjadi pada umumnya sangat berkaitan dengan ketersediaan obat-obatan yang dibutuhkan oleh masyarakat. Terkait dengan kebutuhan obat, dengan jumlah penduduk Indonesia yang terus meningkat serta meningkatnya kesadaran masyarakat terhadap kesehatan, potensi peningkatan pengeluaran kesehatan terhadap GDP perkapita turut serta mendorong pertumbuhan industri farmasi nasional. Pada tahun 2014 di Indonesia terdapat 206 perusahaan pelaku industri farmasi yang mana 33 perusahaan diantaranya merupakan Penanam Modal Asing (PMA). Sedangkan perusahaan farmasi yang terdaftar di Bursa Efek Indonesia adalah 10 perusahaan (www.kementrianperindustrian.com).

Ketergantungan industri farmasi Indonesia pada impor bahan baku menjadi jelas ketika menyadari $90 \%$ dari bahan baku yang digunakan dalam industri farmasi bahan impor. Selain itu, bahan-bahan yang di impor mencapai sekitar 75\% dari total biaya produksi perusahaan farmasi. Dengan demikian jelas bahwa depresiasi rupiah memiliki dampak negatif yang parah pada perusahaan farmasi di Indonesia atau konsumen Indonesia. Depresiasi rupiah yang tajam membentuk masalah yang lebih besar untuk perusahaan farmasi di Indonesia dari perlambatan ekonomi tersebut.

Nilai perusahaan dibentuk melalui indikator nilai pasar saham, sangat dipengaruhi oleh peluang-peluang investasi. Peluang investasi memberikan sinyal positif tentang pertumbuhan perusahaan dimasa yang akan datang, sehingga dapat meningkatkan nilai perusahaan (signalling theory), (Susanti, 2017). Peningkatan hutang diartikan oleh pihak luar tentang kemampuan perusahaan untuk membayar 
Ni Komang Yulan Surmadewi dan I Dewa Gede Dharma Saputra Pengaruh Likuiditas, Leverage,...

kewajiban di masa yang akan datang atau adanya risiko bisnis yang rendah, hal tersebut akan direspon secara positif oleh pasar (Brigham \& Houston, 2006).

Nilai perusahaan memiliki pengertian yang berbeda-beda menurut para ahli, salah satunya menurut pendapat (Husnan, 2006) bagi perusahaan yang belum go public nilai perusahaan merupakan sejumlah biaya yang bersedia dikeluarkan oleh calon pembeli jika perusahaan tersebut dijual sedangkan bagi perusahaan yang sudah go public nilai perusahaannya dapat dilihat dari besarnya nilai saham yang ada di pasar modal. Nilai saham sendiri didefinisikan dengan jumlah lembar saham yang dikalikan nilai pasar per lembar saham ditambah nilai hutang, dengan asumsi jika nilai hutang konstan maka secara langsung peningkatan nilai saham akan meningkatkan nilai perusahaan.

Tujuan perusahaan dapat dicapai melalui pelaksanaan fungsi manajemen keuangan karena tujuan keuangan adalah memaksimumkan nilai perusahaan yaitu dimana satu keputusan keuangan yang diambil akan mempengaruhi keputusan keuangan lainnya dan berdampak pada nilai perusahaan (Hartini, 2017). Nilai perusahaan akan tercermin dari harga sahamnya. Harga pasar dari saham perusahaan yang terbentuk antara pembeli dan penjual disaat terjadi transaksi disebut nilai pasar perusahaan, karena harga pasar saham dianggap cerminan dari nilai aset perusahaan sesungguhnya.

Faktor - faktor yang mempengaruhi nilai perusahaan, yaitu : keputusan pendanaan, kebijakan dividen, keputusan investasi, struktur modal, pertumbuhan perusahaan, ukuran perusahaan. Beberapa faktor tersebut memiliki hubungan dan pengaruh terhadap nilai perusahaan yang tidak konsisten. Nilai perusahaan adalah 
nilai laba masa yang akan datang di ekspektasi yang dihitung kembali dengan suku bunga yang tepat (I. A. R. Sari \& Priyadi, 2016).

Arus kas merupakan cerminan kinerja manajemen keuangan dalam mengambil keputusan keuangan. Arus kas di dalam penelitian ini didefinisikan sebagai likuiditas. Karena likuiditas dapat memberikan kemakmuran terhadap pemegang saham apabila perusahaan memiliki kas yang benar - benar bebas, untuk dibagikan kepada pemegang saham sebagai dividen yang dapat memberikan sinyal positif bagi investor. Menurut (Rakasiwi, W., Ari, \& Rita, 2017), Kebijakan dividen diartikan sebagai pembayaran laba perusahaan kepada pemegang sahamnya. Kebijakan dividen adalah keputusan keuangan, yaitu dengan mempertimbangkan apakah pembayaran dividen akan meningkatkan kemakmuran pemegang saham.

Likuiditas menggambarkan kemampuan suatu perusahaan untuk memenuhi kewajiban finansialnya yang harus segera dipenuhi. Likuiditas akan berpengaruh terhadap besar kecilnya dividen yang dibayarkan kepada para pemegang saham. Dividen merupakan arus kas keluar, maka semakin besar jumlah kas yang tersedia maka dianggap baiknya likuiditas perusahaan, semakin besar pula kemampuan perusahaan untuk membayar dividen (Harjito \& Martono, 2012).

Penelitian mengenai pengaruh kebijakan dividen tersebut telah diteliti oleh (Fadhli, 2015) hasil penelitiannya menyatakan likuiditas yang dinilai dari arus kas bebas perusahaan memiliki pengaruh terhadap nilai perusahaan. Arus kas bebas mencerminkan kinerja manajemen keuangan dalam mengambil keputusan keuangan. Nilai perusahaan dapat memberikan kemakmuran pemegang saham 
Ni Komang Yulan Surmadewi dan I Dewa Gede Dharma Saputra Pengaruh Likuiditas, Leverage,...

apabila perusahaan memiliki kas yang benar-benar bebas, yang dapat dibagikan kepada pemilik saham sebagai dividen.

Leverage merupakan modal yang berasal dari luar perusahaan, dan pada saatnya nanti harus dikembalikan. Kaitan leverage dengan dividen adalah semakin tinggi hutang yang dimiliki, semakin kecil kemampuan perusahaan memenuhi kewajibannya kepada pemegang saham berupa dividen dan semakin buruk penilaian investor terhadap perusahaan. Leverage merupakan rasio yang menunjukkan bagaimana perusahaan mampu untuk mengelola hutangnya dalam rangka memperoleh keuntungan dan juga mampu untuk melunasi kembali hutangnya. Perusahaan yang tidak solvabel adalah perusahaan yang total hutangnya lebih besar dibandingkan total asetnya, (Fahmi, 2014). Leverage dalam penelitian ini diwakili oleh Debt to Assets Ratio (DAR). Debt to Assets Ratio merupakan rasio untu mengukur jumlah aset yang dibiayai oleh hutang untuk menutupi kewajiban jangka pendek dan jangka panjang. (Harahap, 2013) mengungkapkan bahwa "semakin kecil rasio Debt to Assets Ratio, semakin baik kemampuan perusahaan untuk dapat bertahan dalam kondisi yang buruk".

Penelitian mengenai pengaruh leverage terhadap nilai perusahaan telah diteliti oleh (Muh, Yulianeu, \& Fathoni., 2018), hasil penelitian variabel leverage berpengaruh terhadap nilai perusahaan. Hal ini menunjukkan bahwa setiap ada penambahan hutang, maka akan menurunkan nilai perusahaan secara signifikan.

Profitabilitas merupakan rasio yang menggambarkan kemampuan perusahaan dalam menghasilkan laba. Semakin baik rasio profitabilitas maka semakin baik menggambarkan kemampuan tingginya perolehan keuntungan 
perusahaan tersebut (Fahmi, 2014). Menurut Ramdhaningsih dan Utama (2013) pada penelitiannya menyatakan bahwa Rasio rentabilitas atau yang lebih sering disebut profitabilitas adalah kemampuan perusahaan memperoleh laba dalam hubungan dengan penjualan, total aktiva maupun modal sendiri. Rasio profitabilitas ini akan memberikan gambaran tentang tingkat efektifitas pengelolaan perusahaan. Semakin tinggi profitabilitas berarti semakin baik, karena kemakmuran pemilik perusahaan meningkat dengan semakin tingginya profitabilitas. Return on Asset yang menunjukkan tingkat pengembalian terhadap suatu investasi. Semakin tinggi laba perusahaan, kemampuan untuk mengembalikan dana dalam bentuk deviden akan semakin tinggi untuk memakmurkan investor atau pemilik saham.

Salah satu fungsi perusahaan yang sangat penting bagi keberhasilan usahanya dalam pencapaian tujuan salah satunya adalah kondisi manajemen keuangan perusahaan tersebut, Manajemen keuangan mempunyai arti yang penting dalam setiap kegiatan bisnis termasuk dalam kegiatan operasi dan pengelolaan perusahaaan dan juga manajemen keuangan diharapkan dapat menangkap dan mengantisipasi perubahan dimasa yang akan datang untuk secara dini melakukan penyesuaian dan pengambilan keputusan secara tepat dan akurat.

Menurut Kasmir (2011:5), manajemen keuangan adalah segala aktivitas yang berhubungan dengan perolehan, pendanaan dan pengelolaan aktiva dengan beberapa tujuan menyeluruh. Sedangkan (Horne \& John M. Wachowics, 2001) yang dialih bahasakan oleh Dewi Fitriasari (2010:35), mengemukakan bahwa manajemen keuangan adalah segala aktivitas perusahaan yang berhubungan dengan 
Ni Komang Yulan Surmadewi dan I Dewa Gede Dharma Saputra Pengaruh Likuiditas, Leverage,...

bagaimana memperoleh dana, menggunakan dana dan mengelola asset secara menyeluruh sesuai dengan tujuan perusahaan.

Menurut (Goh \& Simanjuntak, 2017), manajemen keuangan merupakan penggabungan dari ilmu dan seni yang membahas, mengkaji dan menganalisis tentang bagaimana seorang manajer keuangan dengan mempergunakan seluruh sumberdaya perusahaan untuk mencari dana, mengelola dana, dan membagi dana dengan saham dan suistainability (keberlanjutan) usaha bagi perusahaan. Manajemen keuangan atau dalam literatur lain disebut pembelanjaan adalah segala aktivitas perusahaan yang berhubungan dengan bagaimana memperoleh dana, menggunakan dana dan mengelola aset tujuan perusahaan secara menyeluruh (Harjito \& Martono, 2012).

Likuiditas dapat diartikan sebagai tingkat kemampuan suatu perusahaan untuk dapat membayar hutang-hutangnya yang telah jatuh tempo (Kasmir, 2015). Menurut Mamduh (2004), likuiditas secara umum diartikan sebagai kemampuan suatu perusahaan memenuhi kewajiban keuangannya dalam jangka pendek atau yang harus segera dibayar. Menurut (Titman, S., 2014), likuiditas adalah kecepatan dimana aset dapat dikonversi menjadi uang tunai tanpa kehilangan nilai. Likuiditas merupakan ukuran kemampuan perusahaan untuk membayar tagihannya secara tepat waktu ketika tanggal pembayaran sudah tiba waktunya.

Tingkat likuiditas perusahaan dapat diukur dengan posisi modal kerja perusahaan yang berjalan dari laba yang didapatkan dalam periode tertentu dimana modal tersebut dapat menunjukkan tingkat keamanan kewajiban jangka pendek. Kewajiban jangka pendek perusahaan sering kali dipenuhi dengan menggunakan aset lancar seperti kas, piutang, surat berharga, ataupun persediaan. Perusahaan yang 
memiliki aset lancar yang besar akan lebih mudah untuk melakukan pendanaan terhadap kegiatan operasionalnya jika pendanaan tambahan diperlukan.

Dilihat dari pihak emiten (manajemen perusahaan), LDR merupakan faktor yang cukup penting dalam kegiatan usaha suatu perusahaan. Ukuran perusahaan bisa dilihat dengan menggunakan total aktiva, penjualan atau modal dari perusahaan tersebut (A. Sari, Putri, \& Handayani, 2016). Dengan demikian, pihak manajemen harus dapat menjaga rasio LDR pada tingkat yang aman (sesuai dengan yang ditetapkan Bank Indonesia, yaitu 80-110\%). Dengan optimalnya LDR maka dalam kegiatan usahanya, perusahaan akan selalu memperoleh keuntungan. Tingkat likuiditas suatu perusahaan mempunyai pengaruh yang cukup signifikan terhadap besar kecilnya perolehan laba perusahaan. Apabila perusahaan dalam menyalurkan kredit dari dana pihak ketiganya tinggi maka otomatis likuiditasnya tinggi dan pendapatan bunganya akan tinggi.

Dalam menjalankan kegiatannya, perusahaan dihadapkan pada beberapa risiko yang harus dikelola untuk mengurangi potensi kerugian yang akan dialami perusahaan. Risiko perusahaan didefinisikan sebagai potensi terjadinya suatu kejadian yang dapat menimbulkan kerugian bagi perusahaan (Ghozali, 2007: 11). Dari beberapa risiko yang dihadapi perusahaan risiko likuiditas merupakan risiko yang krusial.

Risiko likuiditas merupakan risiko akibat ketidakmampuan perusahaan untuk memenuhi kewajiban yang jatuh tempo dari sumber pendanaan arus kas dan/atau dari aset likuid berkualitas tinggi yang dapat diagunkan, tanpa mengganggu aktivitas dan kondisi keuangan perusahaan. Dalam buku Badan 
Ni Komang Yulan Surmadewi dan I Dewa Gede Dharma Saputra Pengaruh Likuiditas, Leverage,...

Sertifikasi Manajemen Resiko (2006), terdapat dua macam risiko likuiditas yang berbeda yaitu likuiditas endogen (endogenous liquidity) dan likuiditas eksogen (exogenous liquidity). Likuiditas endogen adalah likuiditas yang melekat atau inheren pada aset itu sendiri. Likuiditas endogen berhubungan dengan kemampuan perusahaan untuk menjual aset di pasar yang likuid secara cepat dan pada bid/offer spread yang kecil dan tidak terlalu dipengaruhi oleh besarnya transaksi. Sedangkan likuiditas eksogen merupakan likuditas yang diciptakan melalui struktur kewajiban bank, bank dapat melihat mismatch pendanaan tersebut dengan menggunakan liquidity ladder.

Risiko likuditas pada umumnya berasal dari dana pihak ketiga, aset-aset dan kewajiban kepada counter-parties. Komponen off-balance sheet yang paling signifikan dalam likuiditas perusahaan dan pemenuhan pendanaannya. Oleh karena itu, perusahaan mengelola risiko likuiditas agar dapat memenuhi setiap kewajiban financial yang sudah disepakati dengan tepat waktu, dan dapat memelihara tingkat likuiditas yang memadai dan optimal.

Penelitian ini hanya menggunakan profitabilitas yang terkait dengan investasi yaitu return on asset (ROA). ROA merupakan rasio antara saldo laba sesudah bunga dan pajak dengan jumlah asset perusahaan secara keseluruhan. (Munawir, 2010), "Return on asset merefleksikan seberapa banyak perusahaan telah memperoleh hasil atas sumber daya keuangan yang ditanamkan oleh perusahaan”. Rasio ROA ini sering dipakai manajemen untuk mengukur kinerja keuangan perusahaan dan menilai kinerja operasional dalam memanfaatkan sumber 
daya yang dimiliki perusahaan, disamping perlu mempertimbangkan masalah pembiayaan terhadap aktiva tersebut.

Nilai ROA yang semakin mendekati 1 , berarti semakin baik profitabilitas perusahaan karena setiap aktiva yang ada dapat menghasilkan laba. Dengan kata lain semakin tinggi nilai ROA maka semakin baik kinerja keuangan perusahaan tersebut. ROA yang negatif disebabkan laba perusahaan dalam kondisi negatif pula atau rugi. Hal ini menunjukkan kemampuan dari modal yang diinvestasikan secara keseluruhan belum mampu untuk menghasilkan laba.

Penelitian mengenai profitabilitas terhadap nilai perusahaan telah dilakukan oleh Ria Yunita (2014), hasil penelitian menemukan profitabilitas berpengaruh signifikan terhadap nilai perusahaan. Berdasarkan hasil penelitian tersebut penilaian prestasi suatu perusahaan dapat dilihat dari kemampuan perusahaan itu untuk menghasilkan laba. Laba perusahaan selain merupakan indikator kemampuan perusahaan memenuhi kewajiban bagi para penyandang dananya juga merupakan elemen dalam penciptaan nilai perusahaan yang menunjukkan prospek perusahaan di masa yang akan datang. Hasil penelitian Ria Yunita (2014) didukung oleh Corry (2013), Fadhli (2015), dan (Mahendra, 2012) secara parsial dan simultan profitabilitas berpengaruh terhadap nilai perusahaan.

Likuiditas merupakan kemampuan perusahaan memenuhi kewajiban jangka pendeknya yang dapat meningkatkan nilai perusahaan. Perusahaan yang membayar utangnya serta dividen tepat pada waktunya membuat para investor lebih royal dan tidak ragu-ragu untuk meminjamkan dananya kembali ke perusahaan tersebut dan hal ini juga membuat nilai perusahaan dipandang baik dimata investor maupun 
Ni Komang Yulan Surmadewi dan I Dewa Gede Dharma Saputra Pengaruh Likuiditas, Leverage,...

kreditur. Jika perusahaan tidak mampu atau mengalami keterlambatan dalam membayar utang hal ini akan mengakibatkan nilai perusahaan di mata investor dan penyandang dana kurang baik sehingga mereka akan mempertimbangkan atau raguragu dalam berinvestasi dan meminjamkan modalnya kembali. Jadi, dengan melihat likuiditas suatu perusahaan pihak kreditur juga dapat menilai baik buruknya suatu perusahaan tersebut.

$\mathrm{H}_{1}$ : Likuiditas berpengaruh positif terhadap nilai perusahaan.

Perusahaan dengan rasio leverage yang rendah memiliki risiko leverage yang lebih kecil. Oleh karena itu apabila investor melihat sebuah perusahaan dengan aset yang tinggi namun resiko leverage nya juga tinggi, maka akan berpikir dua kali untuk melakukan investasi pada perusahaan tersebut. Karena dikhawatirkan asset tinggi tersebut di dapat dari hutang yang akan meningkatkan risiko investasi apabila perusahaan tidak dapat melunasi kewajibannya dengan tepat waktu. Tingginya rasio leverage menunjukkan bahwa perusahaan tidak solvable, dimana total hutangnya lebih besar dibandingkan dengan total asetnya (Analisa, 2011).

Pada penelitian yang dilakukan oleh (Rudangga \& Sudiarta, 2016) mengemukakan bahwa leverage berpengaruh positif dan signifikan terhadap nilai perusahaan. Arah positif tersebut memiliki arti bahwa semakin tinggi Leverage maka semakin tinggi pula Nilai Perusahaan yang diperoleh.

$\mathrm{H}_{2}$ : Leverage berpengaruh positif terhadap nilai perusahaan.

Dengan melihat defenisi diatas profit atau laba yang tinggi memberikan prospek perusahaan yang baik sehingga dapat memicu investor untuk ikut 
meningkatkan permintaan saham. Semakin baik profitabilitas perusahaan berarti prospek perusahaan di masa depan dinilai semakin baik dimata investor. Apabila kemampuan perusahaan untuk menghasilkan laba meningkat, maka harga saham juga akan meningkat (Setyoko, 2017). Dengan meningkatnya harga saham maka semakin tinggi pula nilai perusahaan.

Pada penelitian terdahulu membahas hubungan profitabilitas terhadap nilai perusahaan dan mempunyai kaitan dengan penelitian ini diantaranya oleh Norma (Hidayah \& Widyawati, 2016) dalam penelitiannya yang berjudul pengaruh profitabilitas, leverage, dan kebijakan dividen terhadap nilai perusahaan food and beverages mengemukakan hasil penelitian bahwa profitabilitas berpengaruh positif terhadap nilai perusahaan. Hal ini berarti semakin tinggi profitabilitas (ROA) maka semakin tinggi kemampuan perusahaan untuk menghasilkan keuntungan dan akan mengakibatkan profitabilitas perusahaan tinggi. Nilai ROA yang tinggi akan memberikan sinyal positif bagi para investor bahwa perusahaan dapat menghasilkan laba dalam kondisi yang menguntungkan. Hal ini menjadi daya tarik bagi investor untuk memiliki saham perusahaan dan akan meningkatkan harga saham sehingga nilai perusahaan pun menjadi meningkat.

$\mathrm{H}_{3}$ : Profitabilitas berpengaruh positif terhadap nilai perusahaan.

\section{METODE PENELITIAN}

Lokasi penelitian dilakukan pada perusahaan subsektor farmasi adalah semua perusahaan farmasi yang mencatatkan sahamnya di Bursa Efek Indonesia atau BEI diakses melalui website www.idx.co.id. Objek penelitian ini adalah nilai 
Ni Komang Yulan Surmadewi dan I Dewa Gede Dharma Saputra Pengaruh Likuiditas, Leverage,...

perusahaan pada perusahaan farmasi yang terdaftar di Bursa Efek Indonesia (BEI) periode 2014-2017 dilihat dari segi likuiditas, leverage dan profitabilitas.

Meningkatnya nilai perusahaan adalah sebuah prestasi, yang sesuai dengan keinginan para pemiliknya, karena dengan meningkatnya nilai perusahaan, maka kesejahteraan para pemilik juga akan meningkat.

$$
\mathrm{PBV}=\frac{\mathrm{MPV}}{\mathrm{BPS}}
$$

Likuiditas adalah ukuran likuiditas yang mengukur besarnya dana yang ditempatkan dalam bentuk kredit yang berasal dari dana yang dikumpulkan perusahaan. Ketentuan batas bawah untuk LDR adalah sebesar $80 \%$ dan batas atas yang dapat ditoleransi adalah 110\% (SE BI No.15/41/DKMP tanggal 1 Oktober 2013). Menurut (Sudirman, 2013) dirumuskan sebagai berikut :

$$
\text { LDR }=\frac{\text { Jumlah Kredit Pihak Ketiga }}{\text { Total Dana Pihak Ketiga }} x 100 \%
$$

Leverage merupakan total hutang dibagi dengan total aset yang Dalam penelitian ini leverage diproksikan dengan debt to assets ratio, yang dihitung dengan rumus sebagai berikut:

$$
\text { Debt to assets ratio }=\frac{\text { Total hutang }}{\text { Total aset }} \times 100 \%
$$

Rasio profitabilitas ini digunakan untuk mengukur kemapuan perusahaan dalam memperoleh keuntungan secara keseluruhan. Pada penelitian ini profitabilitas diproksikan dengan ROA (Return on Assets) yaitu dengan membandingkan antara laba sesudah bunga dan pajak (EAT) dengan total aktiva 
yang digunakan pada Perusahaan, yang dapat dihitung dengan rumus sebagai berikut :

$$
R O A=\frac{\text { EAT }}{\text { Total Aktiva }} X 100 \%
$$

Dalam penelitian ini yang menjadi populasi adalah perusahaan farmasi yang terdaftar di Bursa Efek Indonesia (BEI) periode 2014-2017.

Teknik analisis data yang digunakan dalam penelitian ini adalah analisi regresi linier berganda. Adapun persamaan regresi linier berganda dirumuskan secara matematis sebagai berikut:

$$
\hat{\mathrm{Y}}=\alpha+\beta_{1} \mathrm{X}_{1}+\beta_{2} \mathrm{X}_{2}+\beta_{3} \mathrm{X}_{3}+\mu \mathrm{i}
$$

Keterangan :

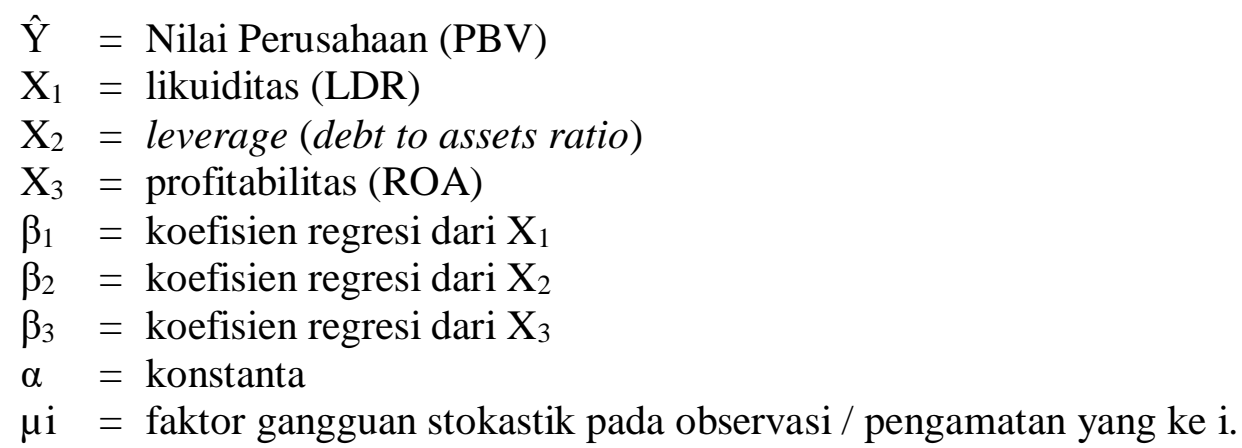

\section{HASIL DAN PEMBAHASAN}

Berdasarkan hasil olahan data dengan program SPSS diperoleh data statistik deskriptif yang memberikan informasi mengenai nilai minimum, nilai maksimum, rata-rata variabel penelitian dan nilai standar deviasi dari masing masing variabel. Hasil statistik deskriptif disajikan pada Tabel 1. 
Tabel 1.

Statistik Deskriptif Variabel Penelitian

\begin{tabular}{|c|c|c|c|c|c|}
\hline & $\mathbf{N}$ & Minimum & Maximum & Mean & Std. Deviation \\
\hline PBV & 36 & ,28 & 35,74 & 4,0650 & 7,03201 \\
\hline LDR & 36 & 10,25 & 51,81 & 28,9144 & 10,79231 \\
\hline DAR & 36 &, 07 & 1,03 &, 3819 &, 24752 \\
\hline ROA & 36 & $-1,63$ & 3,13 & 1,0614 & 1,01107 \\
\hline Valid N (listwise) & 36 & & & & \\
\hline
\end{tabular}

Sumber : Data diolah, 2018

Likuiditas dalam penelitian ini diproksikan dengan (LDR). Berdasarkan hasil statistik deskriptif yang ditunjukkan pada Tabel 1 dengan jumlah data (N) sebanyak 36 dengan periode waktu empat tahun (2014-2017) menunjukkan nilai rata-rata (mean) 28,9144 dengan standar deviasi sebesar 10,79231. Nilai terendah (minimum) dari likuiditas 10,25 dimiliki oleh TSPC ditahun 2014, sedangkan nilai tertinggi (maksimum) dari likuiditas adalah 51,81 dimiliki oleh DVLA ditahun 2015 .

Leverage dalam penelitian ini diproksikan dengan (DAR). Berdasarkan hasil statistik deskriptif yang ditunjukkan pada Tabel 1 dengan jumlah data (N) sebanyak 36 dengan periode waktu empat tahun (2014-2017) menunjukkan nilai rata-rata (mean) 0,3819 dengan standar deviasi sebesar 0,24752. Nilai terendah (minimum) dari leverage 0,07 dimiliki oleh SIDO ditahun 2014 dan 2015, sedangkan nilai tertinggi (maksimum) dari perputaran leverage adalah 1,03 dimiliki oleh SCPI ditahun 2014.

Profitabilitas dalam penelitian ini diproksikan dengan return on asset (ROA). Berdasarkan hasil statistik deskriptif yang ditunjukkan pada Tabel 4.1 dengan jumlah data $(\mathrm{N})$ sebanyak 36 dengan periode waktu empat tahun (2014-2017) menunjukkan nilai rata-rata (mean) 1,0614 dengan standar deviasi sebesar 1,01107. Nilai terendah (minimum) dari profitabilitas (ROA) -1,63 dimiliki oleh SCPI 
ditahun 2014, sedangkan nilai tertinggi (maksimum) dari profitabilitas (ROA) adalah 3,13 dimiliki oleh PYFA ditahun 2017.

Berdasarkan hasil statistik deskriptif yang ditunjukkan pada Tabel 1 dengan jumlah data (N) sebanyak 36 dengan periode waktu empat tahun (2014-2017) menunjukkan nilai rata-rata (mean) 4,0650 dengan standar deviasi sebesar 7,03201. Nilai terendah (minimum) dari ukuran perusahaan 0,28 dimiliki oleh SCPI ditahun 2016 dan 2017, sedangkan nilai tertinggi (maksimum) dari ukuran perusahaan adalah 35,74 dimiliki oleh INAF ditahun 2017.

Dengan menggunakan hasil olahan SPSS kesimpulan dapat ditarik dengan mengunakan Sig (2-tailed). Hasil Uji Normalitas disajikan pada Tabel 2.

Tabel 2.

\section{Hasil Uji Normalitas}

\begin{tabular}{llr}
\hline & & $\begin{array}{c}\text { Unstandardized } \\
\text { Residual }\end{array}$ \\
\hline $\mathrm{N}$ & & 36 \\
Normal Parameters ${ }^{\mathrm{a}, \mathrm{b}}$ & Mean &, 0000000 \\
& Std. Deviation & 1,90177543 \\
Most Extreme Differences & Absolute &, 266 \\
& Positive & 266 \\
& Negative &,- 146 \\
Kolmogorov-Smirnov Z & & 1,597 \\
Asymp. Sig. (2-tailed) & &, 120 \\
\hline Sumber: Data diolah, 2018 & &
\end{tabular}

Berdasarkan hasil analisis pada Tabel 2 diatas menunjukkan bahwa nilai signifikansi variabel bebas dan terikat sebesar 0,120 lebih besar dari 0,05 sehingga dapat disimpulkan bahwa variabel likuiditas, leverage, profitabilitas dan nilai perusahaan berdistribusi normal.

Uji multikolinearitas dilakukan untuk mengetahui apakah ditemukan adanya korelasi antara variabel bebas. Pendeteksian korelasi antara variabel bebas dapat dilihat dari Variance Inflation Factor (VIF), apabila VIF lebih kecil dari 10 maka 
Ni Komang Yulan Surmadewi dan I Dewa Gede Dharma Saputra Pengaruh Likuiditas, Leverage,...

dapat disimpulkan tidak terjadi multikolinearitas. Hasil Uji Multikolinearitas disajikan pada Tabel 3 .

Tabel 3.

Hasil Uji Multikolinearitas

\begin{tabular}{llcr}
\hline & \multicolumn{2}{c}{ Collinearity Statistics } \\
Model & Tolerance & VIF \\
\hline 1 & &, 712 & 1,404 \\
& LDR &, 453 & 2,207 \\
& DAR &, 586 & 1,706 \\
ROA & &
\end{tabular}

Berdasarkan Tabel 3 diatas menunjukkan bahwa nilai Variance Inflation Factor (VIF) dari keempat variabel tidak ada yang lebih dari 10, maka dapat dikatakan tidak terjadi multikolinearitas dari model regresi. Model regresi linier yang baik adalah yang bebas dari adanya multikolinearitas. Dengan demikian, model diatas telah bebas dari adanya multikolinearitas.

Mendeteksi ada tidaknya heteroskedastisitas dapat dilihat dari Grafik Flot antara nilai prediksi variabel terikat (Z-PRED) dengan residualnya (S-RESID). Deteksi ada tidaknya heteroskedastisitas dapat dilakukan dengan melihat ada tidaknya pola tertentu pada Grafik Scatterplot antara S-RESID dan Z-PRED dimana sumbu Y adalah Y yang telah diprediksi, dan sumbu X adalah residual (Y prediksi - Y sesungguhnya) yang telah di studentized. 


\section{Gambar 1. Uji heteroskedastisitas}

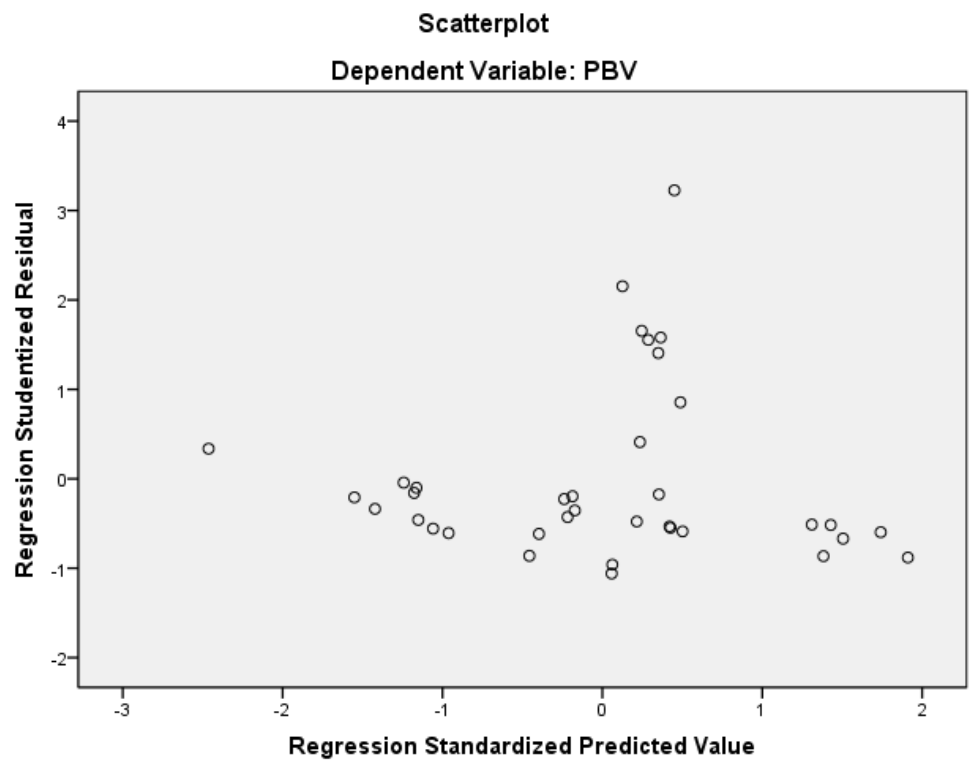

Sumber: Data diolah, 2018

Dari output di atas dapat diketahui bahwa titik-titik tidak membentuk pola yang jelas, dan titik-titik menyebar di atas dan di bawah angka 0 pada sumbu Y. Jadi dapat disimpulkan bahwa tidak terjadi masalah heteroskedastisitas dalam model regresi.

Jika suatu model regresi memiliki gejala autokorelasi, maka hasil prediksi dalam penelitian tersebut akan menyimpang. Hasil Uji Autokorelasi disajikan pada Tabel 4.

Tabel 4.

Hasil Uji Autokorelasi

\begin{tabular}{llrrrrr}
\hline Model & R & R Square & $\begin{array}{c}\text { Adjusted R } \\
\text { Square }\end{array}$ & $\begin{array}{c}\text { Std. Error of the } \\
\text { Estimate }\end{array}$ & Durbin-Watson \\
\hline 1 &, $515^{\text {a }}$ &, 265 &, 196 & 1,98892 & 1,644 \\
\hline
\end{tabular}

Sumber: Data diolah, 2018

Berdasarkan hasil uji autokorelasi pada Tabel 4 diatas menunjukkan bahwa nilai DW sebesar 1,644 dengan nilai dU untuk 36 sampel dengan 4 variabel bebas adalah 1,7245 dan nilai dL adalah 1,2358 sehingga nilai 4-dU sebesar 2,2755. Oleh 
Ni Komang Yulan Surmadewi dan I Dewa Gede Dharma Saputra Pengaruh Likuiditas, Leverage,...

karena nilai D-W statistik 1,644 berada diantara dL dan 4-dU $(1,2358<1,644<$ 2,2755), maka koefisien regresi tidak ada gangguan autokorelasi.

Analisis regresi linier berganda digunakan untuk mengetahui arah dan besarnya pengaruh likuiditas, leverage, profitabilitas dan nilai perusahaan yang terdaftar di Bursa Efek Indonesia. Untuk mempermudah pengolahan data digunakan program SPSS. Hasil analisis regresi linear berganda disajikan pada Tabel 2.

Tabel 5.

Hasil Uji Analisis Regresi Linier Berganda

\begin{tabular}{|c|c|c|c|c|c|c|}
\hline \multirow{2}{*}{\multicolumn{2}{|c|}{ Model }} & \multicolumn{2}{|c|}{$\begin{array}{l}\text { Unstandardized } \\
\text { Coefficients }\end{array}$} & \multirow{2}{*}{$\begin{array}{c}\text { Standardized } \\
\text { Coefficients } \\
\text { Beta } \\
\end{array}$} & \multirow[b]{2}{*}{$\mathbf{t}$} & \multirow[b]{2}{*}{ Sig. } \\
\hline & & B & Std. Error & & & \\
\hline \multirow[t]{4}{*}{1} & (Constant) & 8,327 & 1,903 & & 4,376 &, 000 \\
\hline & LDR &,- 072 & ,037 &,- 350 & $-1,949$ &, 060 \\
\hline & DAR & $-6,785$ & 2,018 &,- 757 & $-3,362$ &, 002 \\
\hline & ROA & $-1,064$ &, 434 &,- 485 & $-2,450$ &, 020 \\
\hline
\end{tabular}

Berdasarkan Tabel 2 diatas dapat dirumuskan persamaan regresi linier berganda sebagai berikut :

$$
\mathrm{Y}=8,327-0,072\left(\mathrm{X}_{1}\right)-6,785\left(\mathrm{X}_{2}\right)-1,064\left(\mathrm{X}_{3}\right)
$$

Keterangan :

$$
\begin{array}{lll}
\mathrm{Y} & = & \text { nilai perusahaan } \\
\mathrm{X}_{1} & = & \text { Likuiditas } \\
\mathrm{X}_{2} & = & \text { Leverage } \\
\mathrm{X}_{3} & = & \text { Profitabilitas }
\end{array}
$$

Persamaan regresi linier berganda pada Tabel 5 tersebut menunjukkan arah masing-masing variabel bebas terhadap variabel terikat. Persamaan regresi tersebut dapat diuraikan sebagai berikut : 
$\beta_{1}=-0,072$ artinya bahwa setiap variable likuiditas meningkat sebesar 1 persen, maka LDR akan mengalami penurunan sebesar 0,072 persen dengan asumsi variabel lain konstan.

$\beta_{2}=-6,785$ artinya bahwa setiap variabel leverage meningkat sebesar 1 persen, maka DAR akan mengalami penurunan sebesar - 6,785 persen dengan asumsi variabel lain konstan.

$\beta_{3}=-1,064$ artinya bahwa setiap variabel profitabilitas meningkat sebesar 1 persen, maka ROA akan mengalami penurunan sebesar 1,064 persen dengan asumsi variabel lain konstan.

Uji kelayakan model dilakukan dengan Uji F dilakukan untuk mengetahui apakah semua variabel bebas yaitu likuiditas, leverage dan profitabilitas layak uji. Apabila hasil dari Uji F menyatakan value $\leq$ 0,05 maka hubungan antara variabelvariabel bebas signifikan terhadap variable terikat. Hasil Uji Kelayakan Model disajikan pada Tabel 3 .

Tabel 3.

Hasil Uji Kelayakan Model

\begin{tabular}{llrrrrr}
\hline Model & & $\begin{array}{c}\text { Sum of } \\
\text { Squares }\end{array}$ & df & Mean Square & F & Sig. \\
\hline 1 & Regression & 45,643 & 3 & 15,214 & 3,846 &, $019^{\mathrm{a}}$ \\
& Residual & 126,586 & 32 & 3,956 & & \\
& Total & 172,229 & 35 & & & \\
\hline
\end{tabular}
Sumber: Data diolah, 2018

Berdasarkan Tabel 3 diatas nilai signifikansi $\mathrm{F}$ adalah sebesar 0,019 yang lebih kecil dari $0,05(\mathrm{~F}<\alpha)$ maka $\mathrm{H}_{0}$ ditolak dan $\mathrm{H}_{1}$ diterima yang berarti variabel independen berpengaruh signifikan secara serempak atau bersama-sama terhadap variabel dependen, sehingga model layak diteliti. 
Ni Komang Yulan Surmadewi dan I Dewa Gede Dharma Saputra Pengaruh Likuiditas, Leverage,...

Koefisiean determinasi berfungsi untuk melihat sejauh mana seluruh variabel independen dapat dijelaskan variabel dependen. Apabila angka koefisien determinasi mendekati 1 , maka pengujian variabel independen terhadap variabel dependen adalah semakin kuat, yang berarti bahwa variabel-variabel independen memberikan hampir semua informasi yang dibutuhkan untuk memprediksi variasi variabel dependen. Hasil Uji Determinasi disajikan pada Tabel 4.

Tabel 4.

Hasil Uji Determinasi

\begin{tabular}{|c|c|c|c|c|c|}
\hline \\
\hline Model & $\mathbf{R}$ & R Square & $\begin{array}{l}\text { Adjusted R } \\
\text { Square }\end{array}$ & $\begin{array}{c}\text { Std. Error of the } \\
\text { Estimate }\end{array}$ & Durbin-Watson \\
\hline 1 &, $515^{\mathrm{a}}$ & 265 &, 196 & 1,98892 & 1,644 \\
\hline
\end{tabular}

Sumber: Data diolah, 2018

Berdasarkan Tabel 4 diatas dapat dilihat nilai dari R Square adalah sebesar 0.265 yang artinya sebesar 26,5 persen variasi nilai perusahaan dipengaruhi oleh likuiditas, leverage, profitabilitas sedangkan sisanya sebesar 73,5 persen dipengaruhi oleh faktor-faktor lain yang tidak dimasukkan ke dalam model penelitian.

Berdasarkan Tabel 5, dapat dilihat bahwa nilai signifikansi likuiditas sebesar $0,060>0,05$, maka $\mathrm{H}_{0}$ ditolak, yang berarti tidak ada pengaruh signifikan antara Likuiditas terhadap Nilai Perusahaan pada Perusahaan Farmasi di BEI periode 2014-2017.

Berdasarkan Tabel 5, dapat dilihat bahwa nilai signifikansi Leverage sebesar $0,002<0,05$, maka $\mathrm{H}_{0}$ diterima, yang berarti ada pengaruh signifikan antara Leverage terhadap Nilai Perusahaan pada Perusahaan Farmasi di BEI periode 20142017. 
Berdasarkan Tabel 5, dapat dilihat bahwa nilai signifikansi Profitabilitas sebesar $0,020<0,05$, maka $\mathrm{H}_{0}$ diterima, yang berarti ada pengaruh signifikan antara Profitabilitas terhadap Nilai Perusahaan pada Perusahaan Farmasi di BEI periode 2014-2017.

Hasil penelitian ini menunjukkan bahwa likuiditas yang diproksikan dengan LDR tidak berpengaruh terhadap nilai perusahaan pada perusahaan farmasi di BEI periode 2014-2017. Jadi hasil penelitian ini tidak mendukung hipotesis pertama yaitu likuiditas berpengaruh positif dan signifikan terhadap nilai perusahaan pada perusahaan farmasi di BEI periode 2014-2017.

Tidak berpengaruhnya LDR terhadap nilai perusahaan menunjukkan bahwa semakin tinggi angka rasio LDR, maka perusahaan tersebut semakin tidak likuid atau tingkat likuiditas rendah, karena dana pihak ketiga yang tersedia yang digunakan untuk membiayai piutang usaha jumlahnya semakin besar membuat dana yang siap digunakan jumlahnya sedikit. Piutang usaha yang besar dengan pengendalian yang kurang dapat menyebabkan risiko seperti terjadi kredit macet sehingga pendapatan bunga perusahaan akan berkurang dan akan berdampak pada likuiditas, karena pendapatan bunga kemungkinan akan digunakan untuk membayar utang jangka pendek. Sehingga akan berdampak pada penurunan nilai perusahaan.

Penelitian ini didukung oleh (Mulyani, Dheasey, \& Azis, 2017) yang menemukan bahwa LDR berpengaruh negatif dan signifikan terhadap nilai perusahaan dan hasil penelitian ini menolak penelitian (Doni, Amboningtyas, \& 
Ni Komang Yulan Surmadewi dan I Dewa Gede Dharma Saputra Pengaruh Likuiditas, Leverage,...

Fathoni, 2018) yang menunjukkan LDR berpengaruh positif dan signifikan terhadap nilai perusahaan.

Hasil penelitian ini menunjukkan bahwa Leverage yang diproksikan dengan DAR berpengaruh signifikan terhadap nilai perusahaan pada perusahaan farmasi di BEI periode 2014-2017. Jadi hasil penelitian ini mendukung hipotesis kedua yaitu leverage berpengaruh positif dan signifikan terhadap nilai perusahaan pada perusahaan farmasi di BEI periode 2014-2017.

Berdasarkan hasil dari penelitian ini menunjukkan bahwa DAR memiliki pengaruh positif terhadap PBV, hal ini mengindikasikan bahwa perusahaan lebih banyak menggunakan asetnya daripada hutangnya, semakin tinggi debt to assets ratio ini menunjukkan perusahaan semakin berisiko, kreditor meminta imbalan semakin tinggi dan kreditor lebih menyukai debt to assets ratio yang rendah, sebab tingkat keamanan dananya menjadi semakin baik.

Hasil dari penelitian ini didukung dengan penelitian sebelumnya oleh I Gusti Ngurah Gede Rudangga dan Gede Merta Sudiarta (2016) mengemukakan bahwa leverage berpengaruh positif dan signifikan terhadap nilai perusahaan. Arah positif tersebut memiliki arti bahwa semakin tinggi Leverage maka semakin tinggi pula Nilai Perusahaan yang diperoleh.

Hasil penelitian ini menunjukkan bahwa profitabilitas yang diproksikan dengan ROA berpengaruh signifikan terhadap nilai perusahaan pada perusahaan farmasi di BEI periode 2014-2017. Jadi hasil penelitian ini mendukung hipotesis ketiga yaitu profitabilitas berpengaruh positif dan signifikan terhadap nilai perusahaan pada perusahaan farmasi di BEI periode 2014-2017. 
Semakin tinggi ROA semakin tinggi keuntungan yang diterima perusahaan. ROA merupakan perbandingan antara laba bersih dengan total aktiva. ROA dapat mempengaruhi Nilai Perusahaan, (Novari \& Lestari, 2016). Dengan ratio ROA yang tinggi memberikan sinyal yang positif bagi investor sehingga harga saham yang diharapkan akan semakin tinggi sehingga harga saham yang tinggi mencerminkan Nilai Perusahaan yang tinggi. Hasil penelitian ini menunjukkan bahwa ROA berpengaruh positif dan signifikan. Artinya setiap kali ROA mengalami peningkatan maka Nilai Perusahaan akan mengalami peningkatan, hasil ini mengindikasikan bahwa Peningkatan keuntungan oleh perusahaan akan mengundang calon investor untuk membeli saham perusahaan sehingga hal tersebut meningkatkan nilai perusahaan.

Hasil penelitian ini mendukung penelitian sebelumnya oleh (Hidayah \& Widyawati, 2016) yang membuktikan secara parsial ROA memiliki pengaruh signifikan terhadap nilai perusahaan.

\section{REFERENSI}

Analisa, Y. (2011). Pengaruh Ukuran Perusahaan, Leverage, Profitabilitas Dan Kebijakan Dividen Terhadap Nilai Perusahaan. Jurnal Akuntansi Universitas Diponegoro Semarang.

Brigham, E. F., \& Houston, J. F. (2006). Dasar- dasar Manajemen Keuangan. Jakarta: Salemba Empat.

Doni, F., Amboningtyas, D., \& Fathoni, A. (2018). Analysis Of Effect Of Capital Structure, Liquidity, Profitability, Total Assets Turnover And Firm Size To The Value Of Companies With Net Sales As A Moderating Variable (Empirical Study on Food And Beverages Companies Listed In Indonesia Stock Exchange 20. Journal of Management Universitas Pandanaran Semarang, 4(4), 2502-7689. 
Fadhli, M. (2015). Pengaruh Likuiditas, Solvabilitas dan Profitabilitas Terhadap Nilai Perusahaan dengan Kebijakan Dividen Sebagai Variabel Moderasi Pada Perusahaan Perbankan, Asuransi dan Lembaga Keuangan lainnya Di Bursa EfekIndonesia Tahun 2010-2013. Jurnal FEKON, 2(2).

Fahmi, I. (2014). Analisis Laporan Keuangan (Cetakan 2). Bandung: Alfabeta.

Goh, T. S., \& Simanjuntak, A. (2017). The Influence of Firm Size, Export Ratio and Earning Variablity On Firm Value with Economic Exposure as Intervening Variable in The Manufacturing Industry Sector. Advances in Economics, Business and Management Research (AEBMR), 36.

Harahap, S. S. (2013). Analisis Kritis Atas Laporan Keuangan. Jakarta: Rajawali.

Harjito, A., \& Martono. (2012). Manajemen Keuangan (Edisi Ke-2). Yogyakarta: Ekonisia.

Hartini, S. (2017). Pengaruh Kepemilikan Manajerial, Kepemilikan Institusional, Kebijakan Dividen, Kebijakan Hutang dan Ukuran Perusahaan Terhadap Nilai Perusahaan. Jurnal Universitas Muhammadiyah, Surakarta.

Hidayah, N., \& Widyawati. (2016). Pengaruh Profitabilitas, Leverage, Dan Kebijakan Deviden Terhadap Nilai Perusahaan Food And Beverages. Jurnal Ilmu Dan Riset Akuntansi, 5(6), 2460-585.

Horne, J. C. Van, \& John M. Wachowics, J. (2001). Prinsip-Prinsip Manajemen Keuangan Terjemah oleh Dewi Fitriasari \& Deny Arnos Kwary (2010). Jakarta: Salemba Empat.

Husnan, S. (2006). Dasar-dasar Teori Portofolio Analisis Sekuritas. Yogyakarta: UPP AMP YKPN.

Kasmir. (2015). Analisis Laporan Keuangan. Jakarta: PT Raja Grafindo Persada.

Mahendra, A. D. (2012). Pengaruh Kinerja Keuangan Terhadap Nilai Perusahaan (Kebijakan Dividen Sebagai Variabel Moderating) Pada Perusahaan Manufaktur Di Bursa Efek Indonesia. Jurnal Manajemen, Strategi Bisnis, Dan Kewirausahaan, 6(2).

Muh, F., Yulianeu, Y., \& Fathoni., A. (2018). The Role Of Corporate Social Responsibility In The Moderating Influence Profitability, Leverage And The Size Of The Company Against The Value Of The Company (The Empirical Study Of Industrial Manufacturing Company Listed In BEI 2012-2016 Period). Journal of Management Universitas Pandanaran Semarang, 4(4), 2502-7689. 
Mulyani, S., Dheasey, A., \& Azis, F. (2017). The Influence Of Liquidity, Profitability, Leverage On Firm Value With Capital Structure As Intervening Variable (In Plantation Sub Sector Company 2012-2016 Listed In BEI). Journal of Management Universitas Pandanaran Semarang, 3(3), ISSN : 2502-7689.

Munawir. (2010). Analisis Laporan Keuangan Cetakan Kelima (Edisi Ke-4). Yogyakarta: Liberty.

Novari, M. P., \& Lestari, V. P. (2016). Pengaruh Ukuran Perusahaan, Leverage, dan Profitabilitas Terhadap Nilai Perusahaan Pada Sektor Properti dan Real Estate. E-Jurnal Manajemen Unud, 5(9), 5671-5694.

Rakasiwi, W., F., Ari, P., \& Rita, A. (2017). Pengaruh EPS, Ukuran Perusahaan, Profitabilitas, Leverage, Sales Groth Dan Kebijakan Dividen Terhadap Nilai Perusahaan Pada Industri Makanan Dan Minuman Yang Terdaftar Di Bursa Efek Indonesia Tahun 2010-2015. Jurnal Dan Riset Akuntansi, 3(3).

Rudangga, G. N. G. I., \& Sudiarta, M. G. (2016). Pengaruh Ukuran Perusahaan, Leverage, dan Profitabilitas Terhadap Nilai Perusahaan. E-Jurnal Manajemen Unud, 5(7), 4394-4422.

Sari, A., Putri, R. M., \& Handayani, N. (2016). Pengaruh Profitabilitas, Ukuran Perusahaan dan Leverage Terhadap Nilai Perusahaan Transportasi. Jurnal Ilmu Dan Riset Akuntansi, 5(9), ISSN : 2460-0585.

Sari, I. A. R., \& Priyadi, P. M. (2016). Pengaruh Leverage, Profitabilitas, dan Growth Opportunity Terhadap Nilai Perusahaan. Jurnal Ilmu Dan Riset Manajemen, 5(10), ISSN : 2461-0593.

Setyoko, B. (2017). Pengaruh Profitabilitas, Kebijakan Hutang, Kepemilikan Manajerial, dan Ukuran Perusahaan Terhadap Nilai Perusahaan. Jurnal Universitas Muhammadiyah, Surakarta.

Sudirman, I. W. (2013). Manajemen Perbankan (Edisi Kedu). Jakarta: Kencana.

Susanti, R. (2017). Pengaruh Financial Leverage dan Return On Equity Terhadap Harga Saham Pada Perusahaan Sub Sektor Farmasi yang Tercatat di Bursa Efek Indonesia. Jurnal Bisma, 1(11).

Titman, S., et al. (2014). Financial Management Principles and Applications. Boston: Pearson Education, Inc. 